\title{
Demografia e antropologia em contraponto: os Enawene-Nawe e suas derivas matrimoniais
}

\begin{abstract}
Marcio Silva*
Este artigo tem um duplo objetivo - um de caráter documental e outro de cunho teórico. Por um lado, o trabalho visa fornecer informações que permitem esboçar o perfil demográfico de um povo ameríndio da Amazônia Meridional Brasileira e sobrepor informações antropológicas a esses dados quantitativos que retomam, na clave das ideias e valores nativos, aspectos de alguma maneira implicados neste perfil. A expectativa é que tal sobreposição, como nos contrapontos musicais, traga sentidos que estão ausentes nas séries de dados consideradas isoladamente. Por outro lado, o artigo procura chamar a atenção para o interesse analítico de um fenômeno empírico raramente explorado, embora muitas vezes intuído pela pesquisa etnográfica: as redes de "anéis matrimoniais" tecidas por esses povos. 0 estudo destas redes traz para o primeiro plano uma região de fronteira interdisciplinar que reclama o aprofundamento do diálogo entre a demografia de sociedades de pequena escala e a antropologia do parentesco, ambas interessadas, cada uma a seu modo, nas formas de reprodução desses coletivos.
\end{abstract}

Palavras-chaves: Enawene-Nawe. Demografia e antropologia. Parentesco. Anéis matrimoniais.

\footnotetext{
* Centro de Estudos Ameríndios, Departamento de Antropologia, Faculdade de Filosofia, Letras e Ciências Humanas, Universidade de São Paulo (USP), São Paulo-SP, Brasil (marciofs@usp.br).
} 


\section{Introdução}

Em um contraponto, duas ou mais melodias são compostas levando-se em conta a simultaneidade de suas execuções. Cada linha melódica, tocada isoladamente, provoca uma dada impressão no espírito. Mas, propositalmente sobrepostas, elas podem produzir novas e inesperadas impressões. Esta técnica musical pode servir como imagem guia do que se apresenta a seguir: a sobreposição de dois enfoques, teórica e metodologicamente distintos, de um mesmo conjunto de temas relativos a um povo ameríndio da Amazônia Meridional, os Enawene-Nawe (doravante EN). Um desses enfoques, solidário à perspectiva do observador, traz informações demográficas essenciais sobre a população; o outro, solidário à perspectiva do observado, fornece dados etnográficos que retomam, na clave das ideias, práticas e valores nativos, questões focalizadas pelo primeiro. Além da divulgação de dados demográficos e antropológicos que favorecem a caracterização de um caso particular, este artigo chama a atenção para um fenômeno praticamente inexplorado por ambos os enfoques, interessados, cada um a seu modo, nas dinâmicas de reprodução da vida social: a deriva das redes matrimoniais.

\section{Observações preliminares}

Os EN, povo indígena de língua aruak, vivem em um território de aproximadamente 750 mil hectares, circunscrito entre as coordenadas $11^{\circ}-13^{\circ}$ Lat. S. e $58^{\circ}-60^{\circ}$ Long. W, na Amazônia Meridional Brasileira. Este território, situado no vale do Rio Juruena, um dos formadores do Rio Tapajós, compreende áreas de floresta tropical, cerrado e de transição (aproximadamente o ponto na Figura 1).

Localizada na parte oeste do Estado de Mato Grosso, a Terra Indígena Enawene Nawe se defronta com o avanço vertiginoso da agroindústria da soja, do garimpo clandestino, da extração ilegal de madeira, da construção de pequenas centrais hidrelétricas, da pecuária extensiva e da pesca esportiva. Em 31 de julho de 2011, a população EN era de 610 indivíduos. Até esta data, em pesquisa realizada pelo autor deste artigo, havia sido registrada a memória de 179 mortos. 0 emprego intensivo do método genealógico (RIVERS, 1910) permitiu integrar 789 pessoas, entre vivos e falecidos, em uma única rede, com as seguintes características gerais: 391 homens, 398 mulheres, 1.368 relações de filiação e 170 matrimônios monogâmicos, envolvendo 159 homens e 165 mulheres. Esta população é distribuída em nove clãs patrilineares (yãkwa), sendo que 76 indivíduos, havidos fora do casamento, pertencem ao clã da mãe (isto é, do avô materno). Ao longo da vida, a imensa maioria se casa uma única vez. Apenas um homem se casou três vezes e nove, duas vezes; entre as mulheres, uma se casou três vezes e três, duas vezes.

Na rede em questão, é possível determinar os quatro avós de 546 indivíduos, a avó materna de 662 e a mãe de 722. A rede tem profundidade genealógica máxima (cadeia linear vertical mais longa) de seis gerações, e média de três. Do ponto de vista matrimonial, os 
EN constituem um isolado demográfico, no sentido estrito da expressão: reunidos em uma única aldeia, formam um coletivo endogâmico. O sistema de parentesco EN corresponde ao tipo iroquês (MURDOCK, 1949; LOUNSBURY, 1964). Este sistema distingue, nas três gerações mediais, parentes consanguíneos colaterais paralelos e cruzados (como, por exemplo, tio paterno e tio materno, filho(a) de germano de mesmo sexo e filho(a) de germano de sexo oposto) e, em contrapartida, cobre com um único termo parentes consanguíneos lineares e colaterais paralelos (como, por exemplo, pai e tio paterno, filho(a) e filho(a) de germano de mesmo sexo). ${ }^{1}$ Esta estrutura conceitual opera associada a um subsistema de tecnônimos exclusivamente voltado aos afins, que são referidos como consanguíneos de consanguíneos (sogro = "avô do filho", nora = "mãe de neto", cunhado = "tio de filho" e assim por diante).

FIGURA 1

Localização da Terra Indígena Enawene-Nawe na América do Sul

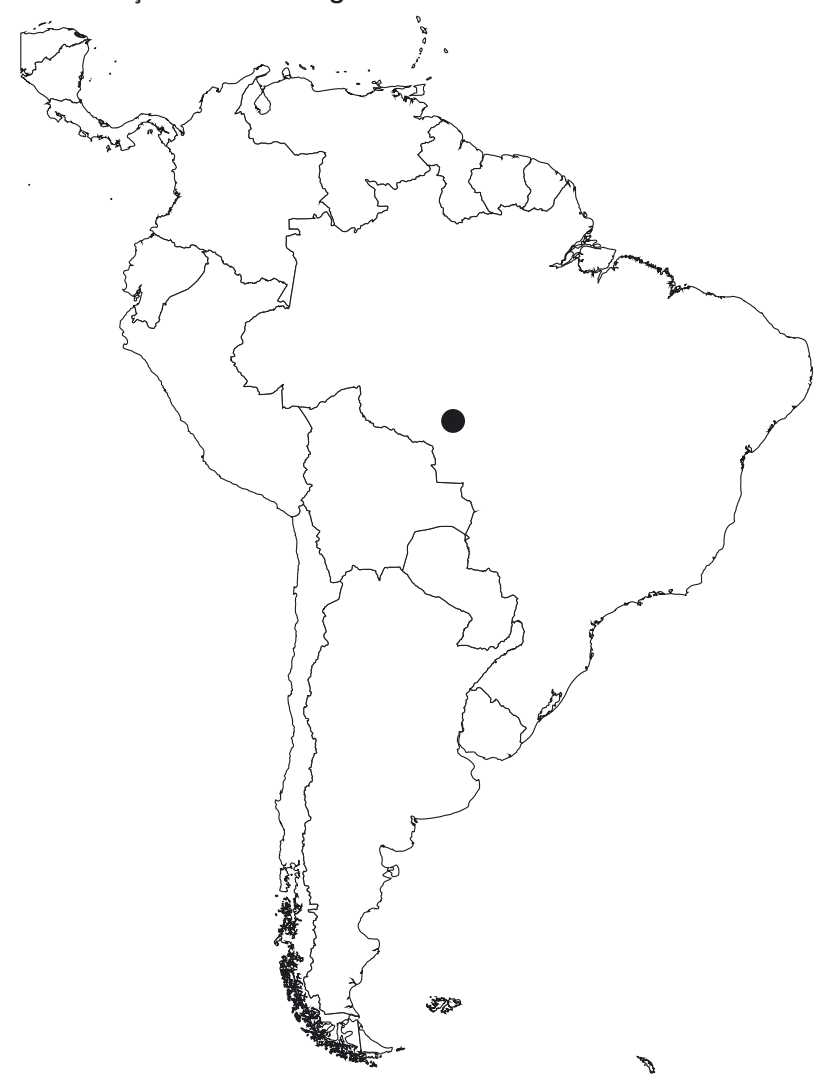

\footnotetext{
$\overline{1} 0$ caso EN corresponde mais precisamente ao que Trautmann e Barnes (1998) denominam de cruzamento tipo- $B$, com variantes diferentes segundo o sexo. Ego feminino opera o que os autores definem como variante 3 , com cruzamento totalmente perdido na geração de Ego ( $\emptyset$ ), mas mantido nas gerações adjacentes (+1 e -1), para parentes de ambos os sexos. Enquanto isso, Ego masculino opera esta variante apenas para parentes do sexo oposto: primas cruzadas são classificadas da mesma forma que as irmãs e primas paralelas. Entretanto, para os parentes do mesmo sexo, Ego masculino opera a variante 1 , que mantém o cruzamento nas três gerações mediais $(+1, \varnothing$ e -1).
} 
O regime matrimonial dos EN corresponde ao que a teoria do parentesco (LÉVI-STRAUSS, [1949] 1967; DUMONT, 1971) define como uma estrutura complexa, isto é, um regime que não formula regra positiva (prescritiva) de casamento, mas apenas proibições. No caso EN, são proscritas as uniões entre pessoas do mesmo clã e entre consanguíneos genealogicamente próximos de clãs distintos (tios, sobrinhos, primos de primeiro grau, etc.). Por outro lado, os EN definem o intercâmbio matrimonial, entre duas famílias de filhos de ambos os sexos, característico das estruturas elementares de parentesco, como a fórmula virtuosa de união matrimonial (SILVA, 2012), para a qual consagram uma expressão na língua nativa (emamanenasê).

Apesar de os EN não se casarem com parentes, os cônjuges nunca são totalmente desvinculados uns dos outros. Consequentemente, cada novo casamento produz novos circuitos de relacionalidade na rede de parentesco, aqui denominados anéis matrimoniais (HOUSEMAN; WHITE, 1996; WHITE, 2004; HAMBERGER et al., 2004). Estes circuitos são formados por cadeias de relações de dois tipos: (A)finidade (casamento) e (C)onsanguinidade (filiação). Assim, um anel A1C1 é um ciclo composto por um casamento e uma cadeia de filiação; um A3C3 é formado por três casamentos e três cadeias de filiação, e assim por diante (DAL POZ; SILVA, 2010). Um anel matrimonial é definido como um circuito da rede genealógica, iniciado por um dado indivíduo e fechado por seu cônjuge (RICHARD, 1993), conforme apresentado na Figura 2, em que homens são representados por triângulos, mulheres por círculos, relações de filiação por flechas e relações de casamento por linhas duplas horizontais. Observa-se que o homem (1) está casado com a mulher (7). Este homem (1), por sua vez, é filho do homem (2), que é filho do homem (3), que tem outro filho (4), que tem um filho (5), que é casado com a mulher (8), que é filha da mulher (6), que tem outra filha (7), que é cônjuge do homem (1).

FIGURA 2

Um anel matrimonial

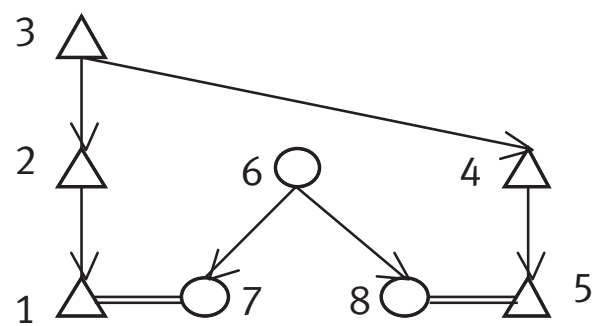

Fonte: Baseado em Richard (1993)

0 circuito representado na Figura 2 é um anel do tipo $\mathrm{A} 2 \mathrm{C} 2$, uma vez que contém dois casamentos ( $1=7$ e $8=5$ ) e duas cadeias de filiação (1-2-3-4-5 e 7-6-8). Neste circuito, nota-se que o homem (1) não está casado com parente, pois, entre (1) e (7), não há um ancestral comum. Mas ele está casado como um parente, no caso, como o seu primo (5), 
já que suas esposas (7) e (8) são irmãs, filhas de (6). 0 censo matrimonial da rede EN, efetuado com o emprego do aplicativo MaqPar, ${ }^{2}$ identificou 16 anéis A1C1, dois A2C1, 2.539 A2C2, zero A3C2 e 144.387 A3C3, perfazendo um total de 147.136 anéis, contendo de um a três casamentos e de uma a três cadeias consanguíneas.

O número de anéis matrimoniais de diferentes tipos de uma rede empírica tem valor indicativo e não absoluto. ${ }^{3}$ Trata-se, por ora, de um recurso "impressionista” e não "diagnóstico" de seu grau de densidade ou rarefação. Da relação entre o número de anéis e os números gerais de uma população (Tabela 1), é possível entrever o grau de imbricação de seus nexos sociais primários. Por estarem diretamente implicados na evolução das redes de parentesco, inaugurando ou reiterando vínculos de aliança entre os indivíduos, os anéis matrimoniais constituem um tema de interesse indiscutível tanto para a demografia de sociedades de pequena escala quanto para a antropologia do parentesco. 0 que vem a seguir corresponde a um passo exploratório nesta direção que, por limitações de espaço, deverá se restringir ao exame, na rede $E N$, dos anéis $A 2 C 2$ e do subconjunto de anéis $\mathrm{A} 3 \mathrm{C} 3$, em que cada cadeia $C$ está constituída por indivíduos de um mesmo clã. A varredura computacional encontrou 370 anéis deste tipo.

\section{Breve caracterização da população EN}

A fonte de informação mais antiga sobre os EN data de 1909, produzida durante a construção da primeira linha telegráfica que integrou núcleos urbanos da Amazônia brasileira ao resto do país. Naquela ocasião, os índios Paresi, vizinhos ao sul dos EN, contaram a Rondon que tinham conhecimento de duas comunidades de "parentes", localizadas à margem esquerda do Rio Juruena (RONDON, 1945). ${ }^{4}$ A segunda fonte sobre os EN teria que esperar mais de meio século para vir à luz. Em 1962, os índios Rikbaktsa, vizinhos a leste, contaram ao padre Tomás Lisboa, membro da missão jesuíta instalada na região, que havia um povo indígena completamente isolado, "de índole pacífica", que "trancava os córregos”, nas imediações dos afluentes do Rio Juruena (LISBOA, 1985). Em 1968, dois sertanistas da Fundação Nacional do Índio observaram, durante um sobrevoo da região,

\footnotetext{
20 aplicativo MaqPar foi programado para encontrar anéis matrimoniais em coletivos de pequena escala (DAL POZ; SILVA, 2009, 2010). Os interessados em testá-lo poderão encontrá-lo em linha, no endereço 〈http://maqpar.zip.net 〉 "outros sites", com uso da senha de visitação "maqpar”. A versão 2.7 foi elaborada na plataforma Microsoft Access $@$. Neste mesmo endereço, encontra-se também um manual de instruções. Para a varredura de redes de grande complexidade, recomenda-se enfaticamente o emprego da nova versão da MaqPar (FERREIRA; FRANCO; SILVA, 2014), elaborada em software livre, em linha no endereço 〈http://www.ime.usp.br/ alvaro/maqpar/〉.

${ }^{3}$ Teoricamente, o número de anéis em populações que, do ponto de vista demográfico, são praticamente idênticas pode variar muito. Um coletivo ameríndio com perfil populacional semelhante ao dos EN, cuja cultura prescreva casamentos com parentes próximos (de primos ou de tio com sobrinha, por exemplo) ou matrimônios poligâmicos certamente apresentaria anéis matrimoniais em número bem maior. Inversamente, em um condomínio urbano de classe média alta, com o mesmo número de pessoas, o número de anéis tenderia a zero.

${ }^{4}$ Os dados populacionais anteriores a 1988 baseiam-se nas seguintes fontes: Rondon (1945); Lisboa (1985, p. 18); Correio do Povo (04/02, 05/02 e 11/02 de 1972); O Estado de S. Paulo (14/08 de 1974); Missão Anchieta (09/01/1978); Funai/DID/ DGPI (27/11/1981); Cedi (1990, p. 452).
} 
dois aldeamentos contíguos como "rodas de bicicleta". São essas as únicas informações disponíveis sobre este povo, no período anterior ao contato.

Finalmente, em 28 de julho de 1974, uma expedição organizada pelos jesuítas fez uma primeira visita aos EN, ocasião em que se estimou um contingente total de cerca de 100 indivíduos. Após uma série de expedições de curta duração, realizadas nos quatro anos subsequentes, o irmão Vicente Cañas, que havia participado da primeira visita, passou a viver com os EN, produzindo um minucioso diário de campo (doravante, DVC), até hoje inédito, com preciosas informações demográficas e antropológicas, atualizadas até às vésperas de seu trágico desaparecimento, em abril de 1987 (CAÑAS, 1978-1987). A partir de 1988, a Operação Amazônia Nativa (Opan), organização não governamental até então parceira da missão jesuíta, passou a responder por serviços de atenção à saúde e proteção do território e incluiu, em suas atividades, a organização de um sistema de registros populacionais de fluxo contínuo que, de 1993 a 2011, passou a contar com a colaboração regular do autor deste artigo. 0 banco de dados permaneceu atualizado até meados de 2011, quando a Opan encerrou suas atividades entre os EN (SILVA; SÁ, 2013). Boa parte dos dados demográficos aqui apresentados foram extraídos deste banco. Outros foram registrados em diários de campo.

A primeira contagem da população, dividida por sexo e faixas etárias de cinco em cinco anos, ocorreu em dezembro de 1977, indicando um contingente de 123 pessoas. Uma segunda, efetuada em outubro de 1978, com informações sobre a distribuição das famílias nas oito casas até então existentes, mostrou uma população de 126 pessoas. Uma terceira, realizada em novembro de 1981, com registro de nomes, idades, sexo, residência e grupos familiares, apontou um total de 131 pessoas. Em um levantamento subsequente, feito em janeiro de 1984, a população aumentou para 148. Outro, em março de 1985, relacionou 164 pessoas. Finalmente, em $1^{\circ}$ de janeiro de 1988, a Opan registrou uma população de 178 indivíduos.

Os mais idosos em 1993 diziam que, no tempo em que seus pais eram crianças (no início do século XX), a população era bem mais numerosa do que aquela encontrada pelos jesuítas. Eles mencionavam também que alguns eventos, a partir de então, foram responsáveis pela drástica diminuição do contingente, como, por exemplo, o uso de roupas de seringueiros, que frequentaram a região até a década de 1940, com consequências deletérias. Além disso, citavam ataques periódicos dos índios Cinta-Larga, seus vizinhos ao norte, com execuções e raptos de mulheres, obrigando-os a sucessivos deslocamentos (também registrados no DVC em 04/12/1982). 0 cruzamento das idades estimadas das pessoas nascidas em meados do século XX com seus locais de nascimento permite entrever a frequência de tais transtornos. Em um intervalo de aproximadamente 20 anos (de 1940 a 1960), há menção de construção de 11 aldeias diferentes, o que foge inteiramente aos padrões verificados antes e depois deste período. Além disso, alguns anos antes da primeira visita dos jesuítas, sete óbitos, em datas muito próximas, foram atribuídos à feitiçaria (ihõlairi) e outros tantos, a atos de retaliação das famílias vítimas do suposto feiticeiro. 
Esses eventos, em poucas semanas, produziram uma redução de aproximadamente $10 \%$ da população.

Pelo exposto, não resta dúvida de que, a partir de 1974, o contingente entrou em uma fase de notável recomposição. As duas pirâmides do Gráfico 1 correspondem a retratos da população, separados por apenas 23 anos: entre 1988 e 2011, a população passou de 178 para 582 pessoas.

GRÁFICO 1

Estrutura populacional por idade e sexo, Enawene-Nawe 1988-2011 (1)

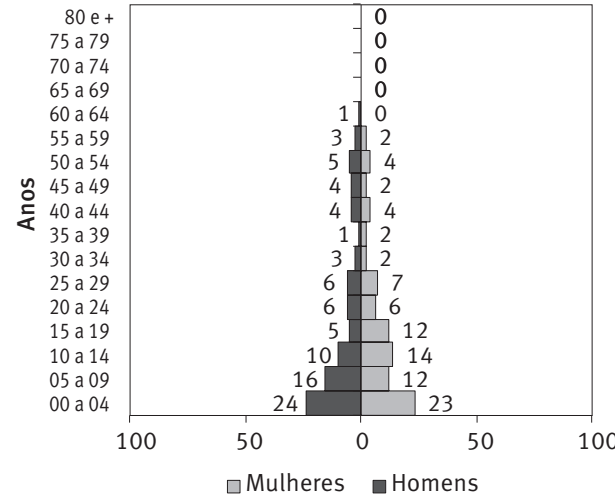

1988

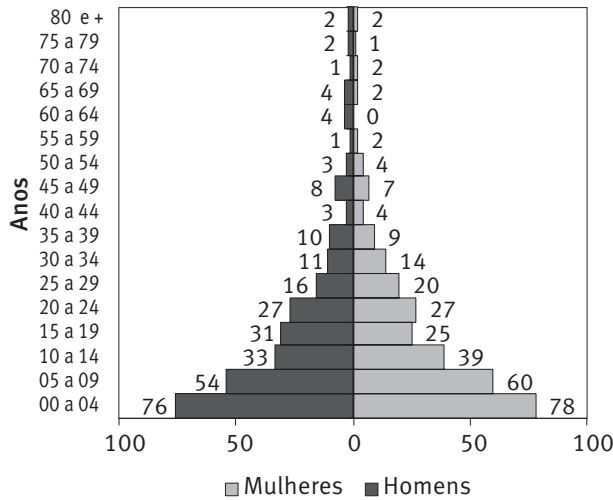

2011

Fonte: Banco de Dados Enawene-Nawe da Operação Amazônia Nativa (Opan).

(1) Em $1^{\circ}$ de janeiro.

A Tabela 1 traz a evolução da população EN em um intervalo de 20 anos. Examinemos mais de perto a evolução deste contingente, cujo tamanho varia apenas pela ocorrência de nascimentos e mortes. Em uma população fechada, que até a década de 1960 parecia virtualmente condenada ao desaparecimento, os dados não deixam dúvidas quanto à ocorrência de um expressivo processo de recuperação. Ao se agregarem os dados em dois intervalos sucessivos de dez anos (1991-2000 e 2001-2010), observa-se que o número de nascidos vivos praticamente dobrou (de 155 para 295), o número de óbitos gerais diminuiu significativamente (de 46 para 33) e, de modo mais discreto, o mesmo aconteceu com o número de óbitos infantis (de 23 para 20).

Embora as condições sanitárias com as quais este povo se defronta ainda estejam longe de padrões ideais, a organização, em 2000, de uma infraestrutura permanente de atenção à saúde ${ }^{5}$ contribuiu para a alteração da tendência na curva de mortalidade geral. Já os números referentes à mortalidade infantil, embora apontem uma discreta tendência de queda, são ainda preocupantes.

\footnotetext{
${ }^{5}$ O Polo Base de Brasnorte, administrado pela Opan, do Distrito Sanitário Especial Indígena de Cuiabá da Fundação Nacional de Saúde.
} 
TABELA 1

Dados populacionais dos Enawene-Nawe 1991-2011

\begin{tabular}{|c|c|c|c|c|c|c|c|c|c|c|c|}
\hline Anos & $\begin{array}{l}\text { Popu- } \\
\text { lação } \\
\text { (1) }\end{array}$ & $\begin{array}{l}\text { Nas- } \\
\text { cidos } \\
\text { vivos }\end{array}$ & $\begin{array}{l}\text { Óbitos } \\
\text { gerais }\end{array}$ & $\begin{array}{c}\text { Óbitos } \\
\text { infantis }\end{array}$ & $\begin{array}{l}\text { População } \\
0-14 \text { anos } \\
\text { (1) }\end{array}$ & $\begin{array}{c}\text { População } \\
>15 \text { anos } \\
\text { (1) }\end{array}$ & $\begin{array}{c}\text { Homens } \\
\text { (1) }\end{array}$ & $\begin{array}{l}\text { Mulheres } \\
\text { (1) }\end{array}$ & $\begin{array}{l}\text { Mulheres } \\
15-49 \text { anos } \\
\text { (1) }\end{array}$ & $\begin{array}{l}\text { Casais } \\
\text { (1) }\end{array}$ & $\begin{array}{c}\text { Novos } \\
\text { Casais } \\
\text { (2) }\end{array}$ \\
\hline 1991 & 211 & 10 & 5 & 5 & 120 & 91 & 103 & 108 & 39 & 39 & 2 \\
\hline 1992 & 216 & 15 & 4 & 2 & 120 & 96 & 107 & 109 & 43 & 41 & 0 \\
\hline 1993 & 227 & 17 & 6 & 2 & 127 & 100 & 114 & 113 & 45 & 40 & 2 \\
\hline 1994 & 238 & 13 & 5 & 4 & 139 & 99 & 115 & 123 & 45 & 39 & 4 \\
\hline 1995 & 246 & 17 & 6 & 0 & 144 & 102 & 119 & 127 & 47 & 42 & 1 \\
\hline 1996 & 257 & 13 & 2 & 2 & 148 & 109 & 125 & 132 & 49 & 41 & 4 \\
\hline 1997 & 268 & 22 & 2 & 0 & 151 & 117 & 133 & 135 & 51 & 45 & 2 \\
\hline 1998 & 288 & 14 & 4 & 2 & 169 & 119 & 142 & 146 & 51 & 47 & 4 \\
\hline 1999 & 298 & 11 & 9 & 5 & 166 & 132 & 144 & 154 & 58 & 50 & 2 \\
\hline 2000 & 300 & 23 & 3 & 1 & 163 & 137 & 148 & 152 & 59 & 50 & 4 \\
\hline 2001 & 320 & 17 & 3 & 0 & 182 & 138 & 157 & 163 & 61 & 54 & 4 \\
\hline 2002 & 334 & 32 & 0 & 2 & 191 & 143 & 164 & 170 & 65 & 58 & 4 \\
\hline 2003 & 366 & 23 & 3 & 1 & 209 & 157 & 180 & 186 & 69 & 62 & 3 \\
\hline 2004 & 386 & 19 & 2 & 2 & 221 & 165 & 190 & 196 & 72 & 63 & 4 \\
\hline 2005 & 403 & 34 & 2 & 1 & 231 & 172 & 196 & 207 & 77 & 67 & 6 \\
\hline 2006 & 435 & 24 & 4 & 2 & 246 & 189 & 211 & 224 & 86 & 72 & 4 \\
\hline 2007 & 455 & 33 & 4 & 3 & 261 & 194 & 223 & 232 & 87 & 76 & 5 \\
\hline 2008 & 484 & 41 & 7 & 5 & 277 & 207 & 233 & 251 & 91 & 81 & 5 \\
\hline 2009 & 518 & 31 & 4 & 2 & 300 & 218 & 252 & 266 & 97 & 86 & 7 \\
\hline 2010 & 545 & 41 & 4 & 2 & 319 & 226 & 267 & 278 & 100 & 92 & 7 \\
\hline 2011 & 582 & & & & 340 & 242 & 282 & 300 & 106 & 98 & 17 \\
\hline
\end{tabular}

Período

1991-2000 $155 \quad 46 \quad 23$

2001-2010 $295 \quad 33 \quad 20$

Fonte: Banco de Dados Enawene-Nawe da Operação Amazônia Nativa (Opan) / Diários de campo.

(1) $\mathrm{Em} 1^{\circ}$ de janeiro.

(2) Até 31 de julho.

Além dos nascimentos em alta, observa-se a nítida manutenção dos padrões de fecundidade ao longo das duas últimas décadas. 0 contingente dobrou nos últimos 13 anos. Além disso, se a distribuição da população por sexo apresentava certo desequilíbrio em 1977, quando foram computados 56 homens e 67 mulheres (DVC, 1997), a evolução dos números sugere uma discreta reversão desta tendência.

Mas o processo de recuperação demográfica cobrou seu preço, que pode ser estimado por meio da evolução da razão de dependência no período em questão. No caso da população EN, incluem-se no segmento dependente apenas os menores de 15 anos, já que o pequeno contingente de idosos continua desempenhando as mesmas atividades produtivas nas quais os adultos mais jovens estão envolvidos. Além disso, com a idade, os idosos passam a acumular obrigações religiosas diretamente implicadas na produção (SILVA, 1998, 2012; e especialmente SANTOS, 2006.). 
0 aumento do peso relativo do contingente de crianças em relação ao de adultos nas duas últimas décadas não deixa dúvidas de que a população EN passa por uma transição, com características análogas às que apontam Pagliaro (2002), para o caso Kayabi do Xingu, e Flowers (1994), para os Xavante de Pimentel Barbosa, com altas taxas de natalidade e acentuada queda da mortalidade ${ }^{6}$ graças, entre outros motivos, às garantias territoriais, ao acesso aos serviços de saúde e ao fim de um período de deslocamentos constantes. Se, no caso EN, por um lado, a recuperação demográfica é, sem dúvida alguma, uma boa notícia, por outro, a elevação do peso relativo da população dependente tem trazido desafios econômicos formidáveis.

A Tabela 2 traz a evolução dos indicadores demográficos no período em questão, apontando nítido declínio da mortalidade, estabilidade dos padrões de fecundidade, modificações profundas na estrutura etária e, consequentemente, na razão de dependência, de uma população que cresce a uma taxa de mais de $5 \%$ ao ano nas últimas duas décadas.

TABELA 2

Evolução dos indicadores demográficos dos Enawene-Nawe $1991-2010$

\begin{tabular}{|c|c|c|c|c|c|c|c|c|}
\hline Anos & $\begin{array}{l}\text { Taxa bruta } \\
\text { de natali- } \\
\text { dade } \\
\text { (1) }\end{array}$ & $\begin{array}{l}\text { Taxa bruta } \\
\text { de morta- } \\
\text { lidade } \\
(2)\end{array}$ & $\begin{array}{c}\text { Taxa } \\
\text { de mortalida- } \\
\text { de infantil } \\
\text { (3) }\end{array}$ & $\begin{array}{c}\text { Taxa de } \\
\text { fecundidade } \\
\text { geral } \\
\text { (4) }\end{array}$ & $\begin{array}{c}\text { Taxa } \\
\text { bruta de } \\
\text { crescimento } \\
(\% \text { a.a. })\end{array}$ & $\begin{array}{c}\text { Razão } \\
\text { de sexo } \\
\text { (5) }\end{array}$ & $\begin{array}{l}\text { Razão } \\
\text { de depen- } \\
\text { dência } \\
(6)\end{array}$ & $\begin{array}{c}\text { Razão de } \\
\text { mulheres } \\
\text { férteis } \\
\text { (7) }\end{array}$ \\
\hline 1991 & 4,7 & 2,3 & 50,0 & 24,4 & 2,4 & 97 & 128 & 56,5 \\
\hline 1992 & 6,8 & 1,8 & 13,3 & 34,1 & 5,1 & 100 & 126 & 65,2 \\
\hline 1993 & 7,3 & 2,6 & 11,8 & 37,8 & 4,8 & 97 & 134 & 66,2 \\
\hline 1994 & 5,4 & 2,1 & 30,8 & 28,3 & 3,4 & 94 & 141 & 57,7 \\
\hline 1995 & 6,8 & 2,4 & 0,0 & 35,4 & 4,5 & 94 & 138 & 58,8 \\
\hline 1996 & 5,0 & 0,8 & 15,4 & 26,0 & 4,3 & 97 & 132 & 59,0 \\
\hline 1997 & 7,9 & 0,7 & 0,0 & 43,1 & 7,5 & 98 & 136 & 60,7 \\
\hline 1998 & 4,8 & 1,4 & 14,3 & 25,7 & 3,5 & 95 & 133 & 53,7 \\
\hline 1999 & 3,7 & 3,0 & 45,5 & 18,8 & 0,7 & 95 & 122 & 60,4 \\
\hline 2000 & 7,4 & 1,0 & 4,3 & 38,3 & 6,7 & 97 & 125 & 63,4 \\
\hline 2001 & 5,2 & 0,9 & 0,0 & 27,0 & 4,4 & 96 & 133 & 59,8 \\
\hline 2002 & 9,1 & 0,0 & 6,3 & 47,8 & 9,6 & 97 & 133 & 61,9 \\
\hline 2003 & 6,1 & 0,8 & 4,3 & 32,6 & 5,5 & 97 & 134 & 59,0 \\
\hline 2004 & 4,8 & 0,5 & 10,5 & 25,5 & 4,4 & 96 & 134 & 58,1 \\
\hline 2005 & 8,1 & 0,5 & 2,9 & 41,7 & 7,9 & 94 & 132 & 59,2 \\
\hline 2006 & 5,4 & 0,9 & 8,3 & 27,7 & 4,6 & 95 & 132 & 62,3 \\
\hline 2007 & 7,0 & 0,9 & 9,1 & 37,1 & 6,4 & 94 & 134 & 60,0 \\
\hline 2008 & 8,2 & 1,4 & 12,2 & 43,6 & 7,0 & 94 & 136 & 56,9 \\
\hline 2009 & 5,8 & 0,8 & 6,5 & 31,5 & 5,2 & 95 & 139 & 57,4 \\
\hline 2010 & 7,3 & 0,7 & 4,9 & 39,8 & 6,8 & 95 & 141 & 56,2 \\
\hline
\end{tabular}

\footnotetext{
${ }_{6}$ Para um exame em detalhe da mortalidade e morbidade na população EN em período recente, ver Weiss (1998, p. 72-94).
} 
(Continuação)

\begin{tabular}{|c|c|c|c|c|c|c|c|c|}
\hline Anos & $\begin{array}{l}\text { Taxa bruta } \\
\text { de natali- } \\
\text { dade } \\
\text { (1) }\end{array}$ & $\begin{array}{l}\text { Taxa bruta } \\
\text { de morta- } \\
\text { lidade } \\
(2)\end{array}$ & $\begin{array}{c}\text { Taxa } \\
\text { de mortalida- } \\
\text { de infantil } \\
\text { (3) }\end{array}$ & $\begin{array}{c}\text { Taxa de } \\
\text { fecundidade } \\
\text { geral } \\
\text { (4) }\end{array}$ & $\begin{array}{c}\text { Taxa } \\
\text { bruta de } \\
\text { crescimento } \\
\text { (\% a.a.) }\end{array}$ & $\begin{array}{c}\text { Razão } \\
\text { de sexo } \\
\text { (5) }\end{array}$ & $\begin{array}{l}\text { Razão } \\
\text { de depen- } \\
\text { dência } \\
(6)\end{array}$ & $\begin{array}{c}\text { Razão de } \\
\text { mulheres } \\
\text { férteis } \\
\text { (7) }\end{array}$ \\
\hline \multicolumn{9}{|l|}{ Período } \\
\hline $\begin{array}{l}1991- \\
2000\end{array}$ & 6,0 & 1,8 & 18,5 & 31,2 & 4,3 & 96,3 & 131,6 & 60,2 \\
\hline $\begin{array}{l}2001- \\
2010\end{array}$ & 6,7 & 0,7 & 6,5 & 35,4 & 6,2 & 95,4 & 134,8 & 59,1 \\
\hline \multicolumn{9}{|l|}{ Período } \\
\hline $\begin{array}{l}1991- \\
2010\end{array}$ & 6,3 & 1,3 & 12,5 & 33,3 & 5,2 & 95,9 & 133,2 & 59,6 \\
\hline
\end{tabular}

Fonte: Banco de Dados Enawene-Nawe da Operação Amazônia Nativa (Opan)/ Diários de campo.

(1) Nascidos vivos por mil habitantes.

(2) Óbitos por mil habitantes.

(3) Óbitos de crianças menores de um ano por mil nascidos vivos.

(4) Número de nascidos vivos na população feminina em idade fértil.

(5) Número de homens para cada grupo de 100 mulheres.

(6) Razão entre o contingente de menores de 15 anos em relação ao de adultos.

(7) Número de mulheres em idade fértil para cada grupo de 100 mulheres.

Encerra-se esta seção com um comentário nativo sobre o significado de alguns dos valores expressos na Tabela 2 decorrente de uma conversa com um enawene sobre 0 vertiginoso crescimento da população em anos recentes. Em dado momento, este autor ponderou que, no início do século XX, quando os EN eram numerosos, os velhos diziam que a população estava distribuída em duas aldeias. Lembrando que o saudoso Irmão Vicente havia contado 126 pessoas (CAÑAS, 1978-1987) quando foi viver com eles no fim da década de 1970, mas que agora a população EN era quatro vezes maior, indagou se não seria a hora de os EN voltarem a ter duas aldeias, que explorassem nichos distintos do território, onde teriam muito mais chances de obtenção de recursos naturais? Diante de materialismo tão crasso, o EN ponderou com a paciência de sempre: "Não! Hoje têm menos cantores (sotakatare).

Cantores são os maestros que dão o tom, a melodia, o ritmo e as letras das canções que, junto com as iguarias, estão no centro do palco cerimonial. São, por excelência, gestores de políticas cósmicas destinadas a aplacar a fúria dos deuses subterrâneos (SILVA, 1998; SANTOS, 2006). Se os EN pararem de cantar e alimentar periodicamente seus deuses dizem os versos de uma trágica canção -, a dor, o sofrimento, a doença e a morte acabarão com eles. 0 EN, à moda dos demógrafos, chamava a atenção para o peso da população que precisava comer sobre a população que sabia cantar. Esta era a razão de dependência que o preocupava. Naquela ocasião, restavam apenas cinco cantores vivos, todos idosos, além de um jovem cantor aprendiz. No tempo do Irmão Vicente, existiam sete virtuosos.

\section{Identidade e diferença}

Temas como nascimento e morte, diferença sexual e etária, evolução histórica da população, etc., em torno dos quais gravitam as estatísticas demográficas, serão agora 
retomados na clave nativa. A expectativa é de que a sobreposição dessas séries de dados produza sentidos nelas ausentes se tomadas isoladamente.

Sobre o passado remoto da população, os EN contam duas histórias, à primeira vista, desencontradas (SILVA, 1998, 2012), já que uma delas postula uma origem única da população e outra a define como um amálgama de povos distintos. Como será possível observar, a contradição é apenas aparente: enquanto a narrativa "monogenista" adquire ressonância diante do caráter endogâmico da população, a narrativa "poligenista" põe em relevo as diferenças no interior do coletivo, produzidas pela divisão da população em clãs. Examinemos muito resumidamente essas duas histórias.

Os EN dizem que são descendentes de um único casal sobrevivente de uma enchente dantesca, provocada por um dilúvio em tempos imemoriais, que praticamente extinguiu a população antiga. Apenas um par de jovens virgens teria escapado da morte por afogamento, refugiando-se no topo de um morro. Com a volta das águas aos níveis normais, esse casal teve muitos filhos, que são os ancestrais da população atual. Mas os EN contam também outra história, em que seus ancestrais viviam no oco de uma pedra, de onde escaparam por uma fenda estreita. A fim de organizar a saída da população em direção ao mundo exterior, formou-se uma fila, que fluía muito bem até que a tentativa de passagem de um homem gordo obstruiu completamente a fenda. Os que estavam atrás deste homem permanecem até hoje na "idade da pedra”. Os atuais EN são descendentes daqueles ancestrais que, por sorte, estavam à sua frente.

Já naquele tempo, os que vieram para fora eram distribuídos em coletivos endogâmicos ("tribos") que se apresentavam como culturas incompletas ou defeituosas. Uma delas, por exemplo, só sabia produzir utensílios em palha, outra só comia carne vermelha, outra praticava casamentos com a sobrinha, outra só bebia água in natura, e assim por diante. Posteriormente, essas tribos foram quase totalmente extintas por catástrofes como ataques de onças, monstros aquáticos, flechas invisíveis e tribos inimigas, assim como incêndios, inundações, etc. Os poucos sobreviventes de cada tribo, guiados por seus deuses, procuraram refúgio justamente na aldeia daqueles que só produziam coisas de palha e, portanto, sabiam fazer casas. A reunião de pessoas com costumes tão bizarros provocou um constrangimento geral. Ficaram, por fim, evidentes os maus costumes que cada tribo ostentava. Envergonhados, eles aprenderam, uns com os outros, as boas práticas culturais, que passaram a vigorar desde então. As tribos passaram a compor os clãs (yãkwa), que, por definição, dependem uns dos outros para se reproduzir. Em suma, os EN se concebem como um consórcio de culturas diferentes, cuja resultante produziu uma combinação de bom gosto. A criação dos clãs, contudo, não transformou as antigas tribos em instituições obsoletas, destituídas de qualquer rendimento sociológico. Se hoje cabe ao sistema clânico presidir a troca matrimonial e a vida ritual, as tribos e seus incontáveis personagens são fontes dos nomes próprios pessoais que toda criança recebe ao nascer. Além disso, correspondem a noções (contemporâneas) implicadas na organização cognitiva do passado. 
A Figura 3 traz o nome das principais tribos que deram origem aos clãs atuais. Observe-se que o número de tribos é maior do que o de clãs. Algumas delas desapareceram com as catástrofes ou não aceitaram os termos do novo "contrato social". Alguns clãs são formados por mais de uma tribo e, pelo menos duas delas, Towarinere e Walitere, se distribuíram em mais de um clã.

Tribos endogâmicas ancestrais aos clãs exogâmicos atuais

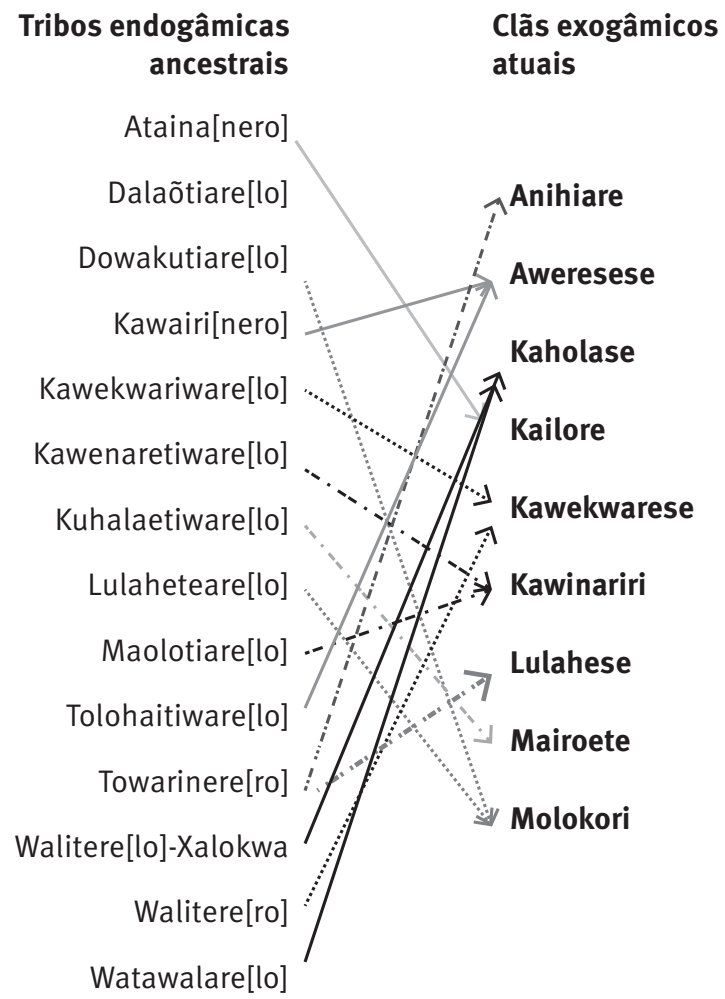

Fonte: Baseado em SILVA (1998, 2012).

\section{As fases da vida e a construção dos gêneros}

Um pequeno manual (SÁ, 1996) elaborado sob a orientação do autor deste artigo, empregado como ferramenta de comunicação nas atividades de atenção à saúde, trouxe à luz uma classificação nativa das idades, baseada em sinais físicos e eventos sociais, inextrincavelmente imbricados. Esta classificação define a pessoa nas diferentes fases da vida. Os EN basicamente dividem a população em duas macrocategorias etárias: a de "crianças" (diñoa) e a de "adultos" (enaha[re lo]), literalmente, "aquel[e a]s que sabem, que têm conhecimento", definindo a puberdade como fronteira entre elas. Grosso modo, essas macrocategorias coincidem com as faixas etárias (0 a 14 anos) / (15 anos ou mais), definidas na Tabela 1. 
Temos aí um dos raros momentos do contraponto em que as duas séries melódicas tocam em uníssono, embora com instrumentos de timbres muito diferentes. 0 ingresso na idade adulta não é determinado pelo número de anos vividos, mas sim favorecido por ritos de passagem à maturidade. Cada uma das macrocategorias etárias é, por seu turno, segmentada em faixas elaboradamente definidas. 0 período da infância distingue nove fases sucessivas, do período intrauterino à puberdade; o da vida adulta, cinco, a partir da iniciação.

QUADRO 1

Classificação nativa das idades na população Enawene-Nawe

\begin{tabular}{|ll|}
\hline Fases & Faixas etárias aproximadas \\
\hline Fases infantis & \\
Tirawa[he lo] & Período intrauterino \\
Wesekoitako[re lo] & Até 2 meses (recém-nascido) \\
Enawehorai[re lo] & De 2 a 6 meses (sempre no colo da mãe) \\
Anolokwa[re lo] & De 7 a 9 meses (começa a engatinhar) \\
Atetwa[re lo] & De 10 a 12 meses (começa a ficar de pé) \\
Atunaha[re lo]se & De 1 a 3 anos (começa a andar) \\
Dinoa[re lo]se & De 3 a 6 anos (começa a adquirir alguma autonomia) \\
Enawa[re lo]tese & De 7 a 11 anos (acompanha os pais nas atividades produtivas) \\
Awita[re lo]se & De 12 a 13 ou 14 anos (chega à puberdade) \\
\hline Fases adultas & \\
Awita[re lo]ti & Da puberdade até nascimento do 1ㅇ filho \\
Enetonasa[re lo] & Após nascimento do 10 filho \\
Kulakarinasa[re lo] & Após 25 anos aproximadamente \\
Kulakala[re lo] & Após 40 anos aproximadamente, quando começa a ter netos \\
Ihita[re lo]ti & Idoso \\
\hline
\end{tabular}

Fonte: Adaptado de SÁ (1996).

Nota: [re lo] são afixos de gênero, respectivamente ["masculino" “feminino"].

De acordo com os Enawene-Nawe, uma nova pessoa se forma no calor do útero materno, com o acúmulo de relações sexuais. Durante o período intrauterino, o feto (tirawa[he lo]) desenvolve, em primeiro lugar, o tronco, os membros superiores e a alma celeste (hesekonase), que ao longo da vida se manifestará nos batimentos cardíacos, na orientação cognitiva e no discurso (SANTOS, 2006; SILVA, 2012). Posteriormente, desenvolve os membros inferiores e, com eles, outra alma (wayakoa[re lo]), que se exprime pela pulsação arterial percebida nos tornozelos e nos joelhos. As duas almas têm destinos post-mortem opostos. A primeira sobe ao céu, enquanto a segunda vai para o mundo das profundezas. Por último, forma-se a cabeça do bebê.

A partir do nascimento, a passagem por cada uma das idades infantis é marcada por dietas apropriadas, cuidados maternos e paternos, uso de adornos corporais e processos de socialização que, pouco a pouco, integram as crianças nas atividades (econômicas, lúdicas, religiosas, etc.) dos adultos. A passagem da última fase da infância (awita[re lo]se) à primeira fase da vida adulta (awita[re lo]ti) reclama um exame mais minucioso, não só pela importância que os EN a ela atribuem, mas também pelas lições que dela podemos extrair. 
Tal passagem é inscrita nos corpos das meninas e dos meninos, por adornos evocativos da potência reprodutiva, de imenso valor na economia simbólica desta cultura, que são conferidos segundo rigorosos protocolos cerimoniais. Estes adornos são a "gravata" peniana (olokori) e as tatuagens no ventre e nos seios (hihõtati), que sinalizam plasticamente a diferença sexual. Não cabe aqui uma descrição detalhada desses ritos, mas apenas um breve esboço de seus contornos gerais. ${ }^{7}$

Na puberdade, os meninos devem esperar o crescimento dos pelos pubianos para iniciar a vida sexual. Esta transformação do corpo é condição necessária, mas não suficiente, para o exercício da sexualidade: os jovens precisam, além disso, ser portadores de uma "gravata" no pênis. Este adorno consiste em uma tira de palha de buriti, de cerca de 30 a 40 centímetros de comprimento por um centímetro e meio de largura, que é amarrada no prepúcio por um laço que lembra um nó de gravata, com o pênis embutido na região pélvica. Durante a madrugada que antecede à colocação do adorno, pai e mãe realizam os últimos preparativos para a cerimônia de acesso à vida adulta de seu filho. Assim que clareia o dia, seus cunhados (atuais ou virtuais) vão buscá-lo em sua residência e o conduzem à casa dos clãs (haiti), construção localizada na área pública da aldeia, onde são guardadas as flautas sagradas. Após a aquisição do adorno, o menino torna-se instantaneamente um adulto, recebendo de seus cunhados novos enfeites corporais, arcos e flechas. Dois ou três cunhados levam o menino de volta ao lar de seus pais, que os aguardam deitados em suas redes. Assim que recebem o filho de volta, é hora de presentear seus iniciadores por suas diligências. Com isso, o jovem conquista permissão para o sexo e o casamento. Em resumo, se os parentes consanguíneos são responsáveis pelo desenvolvimento dos meninos, da concepção à puberdade, são os parentes por afinidade que respondem pela produção dos adultos. Começa aí uma nova etapa na vida deste jovem, notadamente marcada por responsabilidades nas atividades econômicas e pela participação obrigatória na vida ritual.

A passagem de menina a mulher é igualmente ritualizada. Após a primeira menstruação, uma jovem é considerada apta à vida adulta, mas seu corpo não está pronto. Os sinais da eminência desta passagem são o crescimento dos seios e o escurecimento dos mamilos. Tais sinais prenunciam, como os pelos pubianos dos meninos, as demais transformações. Durante sua primeira regra, a menina permanece na rede até que seu pai construa, em sua residência, uma repartição contígua à sua, onde ela permanecerá reclusa até o ciclo seguinte. Terminado o fluxo menstrual, uma tatuadora (sosokaitalo), preferencialmente uma parente da mãe (irmã, mãe ou tia), desenha um conjunto de pequenas linhas verticais em torno dos mamilos e do umbigo, com um objeto cortante e tintura de jenipapo. Uma vez tatuada, seus cabelos são cortados e os adornos substituídos por peças novas. Em seguida, um rezador (howanawitare) benze a jovem, sua casa, as demais casas da aldeia, assim como seus locais de banho e higiene, a casa dos clãs e até mesmo algumas árvores

\footnotetext{
$\overline{{ }^{7} \text { Os interessados encontrarão uma descrição mais cuidadosa em Silva }(2001,2012) .}$
} 
próximas. Ao contrário do adorno peniano, as tatuagens não são pagas, já que sua aquisição não envolve o serviço de afins.

As gravatas penianas e as tatuagens não são meros enfeites que os jovens passam a ostentar, mas definitivamente se tornam partes de seus corpos. Ao morrer, na viagem ao céu (eno), as almas celestes dos EN devem transpor rios caudalosos, guardados por aranhas gigantes. Estes rios são atravessados por pontes que são, na verdade, grandes cobras sucuris. Os arco-íris, fenômenos meteorológicos que os EN abominam contemplar, correspondem ao modo como nós, os vivos, podemos ver essas pontes no céu. Apenas os homens com gravata e mulheres passam de uma margem para outra em segurança. As almas dos demais são sumariamente devoradas pelas aranhas gigantes quando tentam fazê-lo.

Os ritos de passagem à vida adulta não deixam dúvidas de que, em ambos os casos, as idades nunca dizem respeito unicamente aos indivíduos que por elas passam. Ao contrário, a fabricação de adultos é matéria que concerne fundamentalmente aos outros. Outros semelhantes (consanguíneos), no caso das mulheres, outros diferentes (afins), no caso dos homens. A aquisição do adorno e das tatuagens marca o início de uma nova fase da vida, sexualmente intensa, com várias parcerias não apenas em sua faixa etária, mas também envolvendo pessoas mais velhas. Com o tempo, homens e mulheres tendem a estabilizar a parceria com o futuro cônjuge. 0 casamento, contudo, não depende só de tais adornos, mas também da combinação prévia entre os pais dos noivos, efetuada idealmente quando ainda são muito pequenos. Boa parte dessas combinações, dizem os EN, chega a bom termo. Não rara, porém, é a eventual reorientação desses acertos.

Os únicos dois episódios de separação registrados pelo autor deste artigo, no período de 1993 a 2011, envolveram jovens sem filhos. Segundo os EN, o nascimento do primeiro filho é o que põe fim ao longo período de noivado e produz uma relação permanente entre as famílias. Nesse sentido, podemos dizer que são os filhos que literalmente casam os pais. 0 período de noivado pode ser assim resumido: uma vez portador do adorno peniano, um rapaz planta uma pequena roça de mandioca, de cerca de meio hectare, ao lado da roça de seu pai. Um dia, sua futura sogra vai à sua casa e lhe oferece uma bebida à base de mandioca (olõiti), mascada por sua filha. A aceitação desta bebida é sinal do engajamento. Em seguida, o rapaz providencia lenha em sua roça. Como carregar lenha não é tarefa masculina, a mãe do jovem se encarrega de fazê-la chegar a seu destino e exclama "Aí está a lenha!" (Taka maxatĩ!), quando entra na casa da nora. A partir de então, a jovem e sua mãe passam a colher na roça do noivo. Enquanto isso, algumas vezes, o noivo leva, ele próprio, peixe moqueado para sua noiva e seus futuros sogros, e passa a chamá-los de "avós de filho", embora criança alguma tenha nascido. Reciprocamente, os futuros sogros passam a chamá-lo de "pai de neto". Essas formas, como os riscos de um bordado, antecipam a direção da tessitura da rede matrimonial e o "pagamento de peixe", que é um conjunto de prestações que um genro deve honrar, a fim de assegurar a incorporação da criança a seu clã (SILVA, 2008). 
Um dia, o pai da noiva dirige-se à casa de seu futuro genro e diz ao pai do rapaz: "Vim buscar seu filho!" (Hetaî nowa!). Desata e leva sua rede para sua casa, amarrando-a no compartimento vizinho ao seu, onde já está a rede da filha. A coabitação ocorre na primeira fase da idade adulta (Awitare[lo]ti). Promovidos à segunda fase (Enetonasa[re lo]), quando o primeiro filho nasce, não se separam mais.

De $1^{0}$ de janeiro de 1990 a 31 de julho de 2011, ocorreram 91 matrimônios, dos quais quatro envolveram indivíduos viúvos. No universo dos 87 matrimônios restantes, todos contraídos por jovens, a diferença etária entre os cônjuges é de menos de dois anos em $40 \%$ dos casos. Os homens são de dois a três anos mais velhos do que as mulheres em $33 \%$ dos casos, e de quatro a sete anos em 18\%. As mulheres são de dois a três anos mais velhas do que os homens em $7 \%$ e de quatro anos em $1 \%$ dos casos.

A iniciação à fase adulta dos filhos de mulheres solteiras tende a atrasar. Não é, portanto, infrequente que, por ocasião da transição entre a infância e a maturidade, o timbre nativo não coincida com o dos registros de nascimento. 0 mais velho estará na última fase da infância (Awitarese), enquanto o mais novo, na primeira fase da vida adulta (Awetariti).

Nenhum rapaz passa a morar com sua esposa antes dos 14 anos. É a partir dos 16 anos que a prática se torna intensa. A maioria se casa até os 18 anos e, sem exceção, todos estão casados aos 24 anos. Já no universo feminino, a idade mínima de coabitação das jovens é de 13 anos, desde a década de 1980. No último biênio, entretanto, a idade mínima baixou para 11 anos. A Tabela 3 apresenta a população casada, segundo sexo e faixa de idade ao casar.

TABELA 3

População Enawene-Nawe, por idade ao casar, segundo sexo 1으 de janeiro de 2011

\begin{tabular}{lccc}
\hline \multirow{2}{*}{ Sexo } & \multicolumn{3}{c}{ Idade ao casar } \\
\cline { 2 - 4 } & 10 a 14 anos & 15 a 19 anos & 20 a 24 anos \\
\hline População masculina total & 33 & 31 & 27 \\
Homens casados & 1 & 25 & 25 \\
População feminina total & 39 & 25 & 27 \\
Mulheres casadas & 15 & 16 & 27 \\
\hline
\end{tabular}

Fonte: Banco de Dados da Operação Amazônia Nativa (Opan).

Das 37 mulheres casadas, com idade de 17 a 24 anos, em $1^{10}$ de janeiro de 2011, 12 já eram mães de filhos não necessariamente de seus atuais maridos. Em um universo de 111 mulheres, nascidas entre 1955 e 1997, 59\% tornaram-se mãe pela primeira vez com idade entre 15 e 17 anos, $17 \%$ com menos de 15 anos e $24 \%$ com idade superior a 17 anos. Já no universo de 85 homens, nascidos entre 1955 e 1994, a maioria (53\%) foi pai pela primeira vez com idade entre 17 e 19 anos, $26 \%$ com menos de 17 anos e $21 \%$ com idade superior a 19 anos. 0 Gráfico 2 detalha este quadro por idade simples: 0 eixo vertical corresponde ao número absoluto de indivíduos e o eixo vertical, à idade em que foi pai ou mãe pela primeira vez. 
GRÁFICO 2

População Enawene-Nawe, por sexo (1), segundo idade por ocasião do nascimento do primeiro filho 10 de janeiro de 2011

Fonte: Banco de Dados da Operação Amazônia Nativa (Opan).

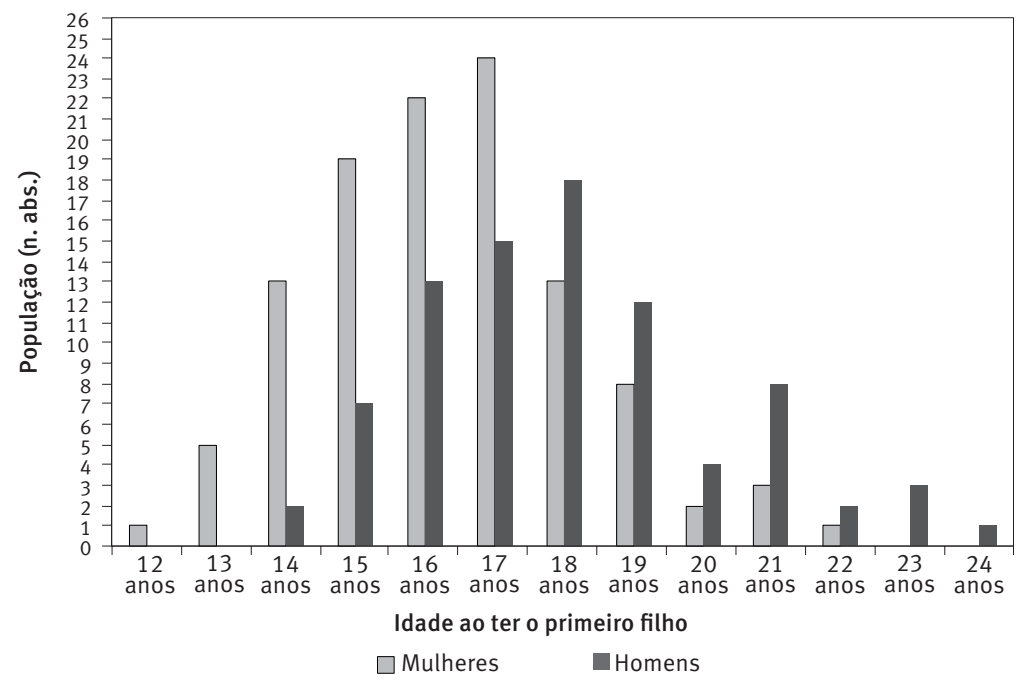

(1) Mulheres nascidas entre 1955 e 1997 e homens nascidos entre 1955 e 1994.

A Tabela 4 traz o universo de homens e mulheres, agrupados por faixas de cinco anos, nascidos entre 1955 e 1994, e a idade em que tiveram seu primeiro filho. Observe-se que 0 padrão para ambos os sexos é praticamente inalterado neste intervalo de quatro décadas. Sempre que perguntados, homens e mulheres afirmam, com as duas mãos espalmadas em direção ao interlocutor, que o "correto, o bonito" (ihekokô) é ter dez filhos, cinco homens e cinco mulheres, nascidos alternadamente (“ená, wirõ, ená, wirô, ená, wirô,...."). ${ }^{8}$ exame dos dados revela que a prática está muito próxima do ideal nativo. Também se chama a atenção para uma discreta tendência de queda do intervalo médio de nascimentos sucessivos na população mais jovem.

TABELA 4

Homens e mulheres Enawene-Nawe casados nascidos entre 1955 e 1994, idade média na primeira paridade, número médio de filhos e intervalo entre nascimentos sucessivos

\begin{tabular}{|c|c|c|c|c|c|c|c|c|}
\hline \multirow[b]{2}{*}{ Indicadores } & \multicolumn{8}{|c|}{ Período de nascimento } \\
\hline & $\begin{array}{l}1955- \\
1959 \\
\end{array}$ & $\begin{array}{c}1960- \\
1964\end{array}$ & $\begin{array}{c}1965- \\
1969\end{array}$ & $\begin{array}{c}1970- \\
1974\end{array}$ & $\begin{array}{l}1975- \\
1979 \\
\end{array}$ & $\begin{array}{c}1980- \\
1984 \\
\end{array}$ & $\begin{array}{l}1985- \\
1989 \\
\end{array}$ & $\begin{array}{c}1990- \\
1994 \\
\end{array}$ \\
\hline Homens casados & 4 & 6 & 8 & 7 & 7 & 21 & 18 & 14 \\
\hline Idade média ao ter o 10 filho (em anos) & 18,3 & 18,0 & 18,8 & 18,4 & 17,4 & 18,6 & 18,0 & 17,1 \\
\hline Número médio de filhos & 10,3 & 9,8 & 9,3 & 9,7 & 8,0 & 5,1 & 3,2 & 2,1 \\
\hline Intervalo intergenésico (em anos) & 2,8 & 2,6 & 2,6 & 2,2 & 2,3 & 2,4 & 2,3 & 2,1 \\
\hline Mulheres casadas & 4 & 8 & 6 & 12 & 14 & 19 & 20 & 25 \\
\hline Idade média ao ter o 1 filho (em anos) & 16,8 & 15,8 & 15,8 & 15,7 & 16,5 & 16,9 & 16,8 & 16,2 \\
\hline Número médio de filhos & 10,0 & 8,8 & 9,3 & 10,4 & 8,0 & 5,3 & 3,7 & 2,1 \\
\hline Intervalo intergenésico (em anos) & 2,5 & 2,9 & 2,6 & 2,4 & 2,3 & 2,5 & 2,4 & 2,1 \\
\hline
\end{tabular}

Fonte: Banco de Dados da Operação Amazônia Nativa (Opan).

${ }^{8}$ Ena $=$ homem, Wirõ $=$ mulher. 
Dois últimos aspectos devem ser assinalados sobre os temas descritos. De um total de 503 nascimentos, ocorridos de 1ํ de janeiro de 1990 a 31 de julho de 2011, 66 (13\%) são filhos de "pai genérico" (Enawene-hetai, lit. “filhos de Enawene”, não de determinado homem), concebidos fora do casamento, por mulheres solteiras ou viúvas. É importante notar que o número médio de filhos de mães sem marido é bem mais baixo do que aqueles assinalados anteriormente, oscilando entre 1 e 3 ao longo da vida. 0 intervalo entre nascimentos sucessivos de filhos sem pai, da mesma forma, escapa aos padrões já registrados, girando em torno de 4,3 anos.

\section{A rede matrimonial em contraponto}

A sobreposição de dados demográficos e antropológicos cria condições privilegiadas para a observação da rede empírica de anéis matrimoniais. Nos limites deste artigo, apresenta-se um rápido esboço das dinâmicas que conferem a esta rede uma dada curvatura. Em primeiro lugar, convém lembrar que o objeto em questão, por mais exaustivo que possa parecer, corresponde a um fragmento daquilo que pretende representar, por duas razões triviais: uma delas decorre das lacunas inevitáveis de qualquer pesquisa; e a outra compreende o pressuposto de que uma rede genealógica é, por definição, infinita, já que para qualquer pessoa nela incluída é possível supor um ascendente. 0 fragmento, ao contrário, define um intervalo temporal, teoricamente compreendido entre a data de nascimento do indivíduo mais antigo e a data de nascimento, óbito ou casamento mais recente.

Contudo, a determinação deste intervalo não é uma tarefa simples. Em redes de coletivos tradicionais, pequenos e relativamente fechados como as populações ameríndias, costuma ser muito difícil obter informações precisas sobre o contingente de mortos localizados em sua franja superior. Há dezenas desses casos na rede EN, que são os pais das pessoas mais velhas, sobre as quais os únicos rastros são aqueles pressupostos nos nexos de parentesco entre os vivos. Com o passar do tempo e novos óbitos, esses rastros são definitivamente apagados da memória social e é só lá que uma rede existe.

Os EN particularmente colaboram com este apagamento. É muito perigoso ficar pensando nos mortos, alertam os EN. A saudade é um sentimento que não brota dos vivos. São os mortos, nostálgicos de seus entes queridos, que de longe enviam a saudade para vivos que, enlutados, adoecem, morrem e voltam para sua companhia. Por isso, aos vivos, de modo nenhum convém conversar sobre pessoas falecidas ou sequer pronunciar seus nomes. Quando é absolutamente necessário fazê-lo, sempre em voz baixa, é de bom tom dar tapas na boca em sinal de arrependimento da incontinência verbal.

Este formidável complicador da pesquisa genealógica tem, por seu turno, o mérito indiscutível de produzir não parentes na rede com maior rapidez e, consequentemente, ampliar extraordinariamente as possibilidades matrimoniais em um coletivo tão pequeno, no qual o casamento de parentes é proibido. 
Tomando por base as idades dos quatro indivíduos vivos mais velhos na rede em 2011 (Figura 2), com 80 anos ou mais, estabelecemos que seus pais, falecidos há muitos anos, mas de quem guardavam lembrança, seriam seus indivíduos mais antigos. Levando em conta as informações fornecidas nas Tabelas 3 e 4, podemos estimar a profundidade temporal de nossa rede em cerca de 100 anos.

Dito isso, retomemos o anel matrimonial esboçado na Figura 2. Diante daquele esquema, podemos supor duas situações:

- as mulheres (7) e (8) têm o mesmo pai e, portanto, pertencem ao mesmo clã; ${ }^{9}$

- as mulheres (7) e (8) são irmãs apenas por parte de mãe, filhas de homens de clãs distintos.

No primeiro caso, (1) se casou como seu primo (5), isto é, redobrou a aliança matrimonial previamente estabelecida, já que se casou no mesmo clã. No segundo caso, (1) não se casou como seu primo (5), isto é, não redobrou a aliança efetuada por seu primo (5), já que (7) e (8) são de clãs diferentes.

Retomemos as informações gerais sobre a rede EN fornecidas acima: nela existem 2.539 circuitos semelhantes ao esquema representado na Figura 2, isto é, anéis A2C2, constituídos por duas sequências consanguíneas intercaladas por dois casamentos (Tabela 5). No universo de 170 uniões registradas na rede, é possível determinar a avó materna dos cônjuges em 96 casos. Neste conjunto, 63,5\% dos casamentos são redobramentos de aliança de consanguíneos próximos (61 casos). Assinale-se também que uma pessoa, ao se casar, pode realizar mais de um redobramento (gerar mais de um anel). É o que comumente acontece. Existem 201 anéis de redobramentos de aliança envolvidos nesses 61 casamentos, dos quais 126 (63\%) são de parentes do sexo oposto, 75 (37\%) do mesmo sexo e 28 (14\%) de ambos os sexos. 0 número médio de redobramentos por casal é 3 (máximo de 10 , mínimo de 1). Do total de redobramentos, $52 \%$ são efetuados por esposas e $48 \%$ por maridos. Em outras palavras, homens e mulheres redobram aliança mais ou menos na mesma proporção. Para ambos, o redobramento de aliança de parente de sexo oposto é duas vezes mais frequente do que o de aliança de parentes do mesmo sexo: respectivamente, $62 \%$ e $38 \%$, para os homens, $63 \%$ e $37 \%$, para as mulheres.

É possível também determinar o grau de cruzamento - paralelo $(\mathrm{P})$ ou cruzado $(\mathrm{X})$-, segundo o cálculo iroquês (TRAUTMANN; BARNES, 1998), das cadeias consanguíneas que se manifestam nos anéis matrimoniais em questão. Convencionemos que a primeira cadeia começa no indivíduo que redobra a aliança (ego) e termina em seu parente consanguíneo que vê sua aliança redobrada. A segunda cadeia começa no cônjuge deste parente e termina na esposa de ego. Na rede EN, a maioria dos anéis com redobramento de aliança é composta por um par de cadeias paralelas: $\mathrm{P}-\mathrm{P}=66 \%$. As frequências das outras combinações são as seguintes: $\mathrm{X}-\mathrm{P}=14 \%, \mathrm{P}-\mathrm{X}=12 \%, \mathrm{X}-\mathrm{X}=8 \%$.

\footnotetext{
${ }^{9}$ No caso de as mulheres (7) e (8) serem filhas de pais diferentes, mas do mesmo clã, (1) da mesma forma redobra a aliança de seu primo (5).
} 
Os casamentos conectam cadeias consanguíneas de um anel, produzindo um caminho fechado com um dado perfil. No universo de redobramentos em questão, o perfil mais frequente, com $75 \%$ das ocorrências, é o de duas cadeias em que seus indivíduos em posição de aliança ${ }^{10}$ são parentes da mesma geração $(G \emptyset-G \emptyset) \cdot{ }^{11}$ Os demais perfis de reencadeamento verificados na rede $E N$ são os seguintes: (G $\emptyset$ - G-1 e $G+1$ - $G \emptyset=11 \%$ ), $(\mathrm{G}+1-\mathrm{G}-1=5 \%),(\mathrm{G}+1-\mathrm{G}-2$ e $\mathrm{G}+2-\mathrm{G}-1=3 \%),(\mathrm{G}+2-\mathrm{G}-2=2 \%),(\mathrm{G}-1-\mathrm{G} \emptyset, \mathrm{G}-1-\mathrm{G}+1$, $\mathrm{G}-1-\mathrm{G}+2, \mathrm{G}-2$ - G+1, G-1 - G-1 e G+1 - G+1 = 1\%).

Finalmente, outro aspecto fundamental é o intervalo temporal entre o primeiro casamento e o que redobra a aliança (isto é, aquele que "fecha" o anel). Observe-se que praticamente dois terços dos anéis se fecham antes do primeiro casamento completar dez anos e, mais de quatro quintos, antes de completar 20 anos, o que sugere um regime de reciprocidade de ciclos relativamente curtos.

TABELA 5

Intervalos temporais entre os casamentos de um anel A2C2

População Enawene-Nawe

\begin{tabular}{ccc}
\hline Intervalo do redobramento (em anos) & Número de anéis & \% (cumulativo) \\
\hline 0 а 4 & 74 & 37,0 \\
5 9 & 129 & 64,0 \\
10 a 14 & 159 & 79,0 \\
15 a 19 & 172 & 86,0 \\
20 24 & 176 & 88,0 \\
25 a 29 & 180 & 90,0 \\
30 а 39 & 190 & 95,0 \\
40 a 49 & 201 & 100,0 \\
\hline
\end{tabular}

Fonte: Banco de Dados da Operação Amazônia Nativa (Opan).

Até aqui, esta análise privilegiou circuitos matrimoniais $\mathrm{A} 2 \mathrm{C} 2$, que descrevem redobramentos de aliança de consanguíneos (isto é, de casamento com um afim de um consanguíneo). Vimos que no universo dos 96 casamentos privilegiados pela análise, $61(63,5 \%)$ podem ser interpretados dessa forma. Duas ou três palavras devem ser ditas sobre os circuitos $A 3 C 3$, que descrevem casamentos com um afim de um afim. Ao serem selecionados os anéis $\mathrm{A} 3 \mathrm{C} 3$, em que cada cadeia consanguínea é formada exclusivamente por indivíduos de um mesmo clã, trazemos para o primeiro plano um aspecto fundamental da rede, não focalizado até agora, que são as unidades de troca matrimonial. Foram encontrados 370 anéis deste tipo, que permitem descrever 59 situações de reencadeamento de aliança de afim. E isso não é tudo. Muito comumente, um único casamento pode estar ao mesmo tempo envolvido em anéis de tipos diferentes (A2C2 e A3C3). Mas os conjuntos de casamentos envolvidos em cada uma dessas configurações não estão completamente

\footnotetext{
${ }^{10}$ Na Figura 2, os indivíduos em posição de aliança são (1), (5) e (7), (8), que são as pontas das duas cadeias consanguíneas.

${ }^{11}$ Diferença geracional entre indivíduos em posição de aliança de um dado anel: $G \emptyset=$ de mesma geração; $G+1, G+2 \ldots=$ de primeira, segunda ... geração ascendente; $\mathrm{G}-1, \mathrm{G}-2$... = de primeira, segunda ... geração descendente; $\mathrm{G}+1, \mathrm{G}-1=\mathrm{de}$ gerações adjacentes, G+2, G-2 = de gerações alternadas.
} 
sobrepostos. 0 efeito da simultaneidade desses dois tipos de anel permite interpretar, na rede $\mathrm{EN}$, nada menos do que $81,3 \%$ dos casamentos como redobramentos do tipo $\mathrm{A} 2 \mathrm{C} 2$, como reencadeamentos do tipo $\mathrm{A} 3 \mathrm{C} 3$ ou como ambas as coisas.

\section{Conclusão}

Em parte alguma, as escolhas matrimoniais são aleatórias. Esta é a premissa fundamental dos estudos de parentesco, da qual decorre o postulado da universalidade da proibição do incesto (LÉVI-STRAUSS, [1949] 1967). Todos os coletivos humanos definem "processos destinados a repartir as famílias por campos rivais ou aliados, entre os quais poderá e deverá desenrolar-se o grande jogo do casamento" (LÉVI-STRAUSS, [1956] 1983, p. 87). Ora, este jogo é precisamente o ponto de fuga do contraponto sugerido neste texto. Em populações como a EN, as escolhas matrimoniais se definem em espaços modelados por laços de consanguinidade e afinidade entre pessoas que nunca estão totalmente desvinculadas umas das outras. Consequentemente, cada novo casamento produz novos ciclos empíricos de relacionalidade (anéis matrimoniais) pelos quais a rede populacional evolui no tempo. 0 estudo dos anéis tem o pressuposto de que cada casamento em uma dada rede populacional é de algum modo condicionado por casamentos que o precederam e contribui, de alguma forma, para a determinação de casamentos subsequentes (HOUSEMAN; WHITE, 1996, p. 61).

Por outro lado, não há como definir a priori as implicações (antropológicas ou demográficas) dos redobramentos de aliança em um dado coletivo, bem com os fatores que influenciam a duração de seus intervalos. Somente a pesquisa empírica, em região de fronteira interdisciplinar, teria eventualmente condições de lançar luzes sobre esses aspectos em cada caso. Do ponto de vista antropológico, o estudo dos redobramentos da rede EN traz à tona um regime matrimonial que, à primeira vista, lembra uma charada, já que os EN se pensam como um coletivo em que todos são parentes, ninguém se casa com parente, mas todos se casam entre si. Poderíamos dizer ainda, embaralhando a macrotipologia lévistraussiana, que os EN, de direito, operam um regime complexo, apenas com proibições matrimoniais, mas, de fato, um regime elementar de troca restrita multibilateral. Aos demógrafos, caberá apontar as implicações demográficas do regime de alianças em questão.

A tese deste artigo é a de que o estudo dos anéis matrimoniais de uma rede corresponde a uma via privilegiada de acesso à dinâmica de populações tradicionais, relativamente fechadas e pequenas. Tais estruturas reticulares do parentesco (Figura 2), trazidas à tona pela análise computacional, têm sido interpretadas como manifestações de "redobramentos" (HÉRITIER, 1981) ou "reencadeamentos” (RICHARD, 1993) de aliança. A exploração dessas mesmas estruturas matrimoniais, por especialistas em demografia de sociedades de pequena escala, há de acrescentar a elas outros significados. 0 ponto de partida desta parceria interdisciplinar, contudo, depende de um acordo prévio: a definição dos eventos 
matrimoniais de uma população como fenômenos em cadeia, em que "cada casamento é apenas um momento em uma série de intercâmbios simbólicos e materiais” (BOURDIEU, 1972, p. 1120), que criam ou reiteram nexos pelos quais circulam, em uma população, signos, direitos, afetos, prerrogativas, saberes, bens, substâncias corporais, deveres, serviços, etc., produzindo "um estado de dependência recíproca [...] entre os atores de uma dada rede" (GREGORY, 1982, p. 19 e 29). Consequentemente, os fatores que influenciariam a duração dos intervalos entre os casamentos estariam, de alguma forma, refratados pelos fluxos de intercâmbio como aqueles aqui referidos.

Por essas razões, os anéis matrimoniais devem cruzar os limites da província dos estudos de parentesco em direção à região de fronteira interdisciplinar. Desde que tocadas simultaneamente, as linhas melódicas da demografia das sociedades de pequena escala e da antropologia do parentesco certamente encontrarão ressonâncias no fenômeno em questão. 0 tratamento computacional das redes empíricas garante as condições iniciais desses contrapontos (DAL POZ; SILVA, 2009; FERREIRA; FRANCO; SILVA, 2014), afinando em mesmo tom instrumentos disciplinares de timbres tão distintos e criando novas condições de ataque de questões ainda não esgotadas, embora algumas delas muito antigas. Aí vão apenas alguns exemplos:

- Quais variáveis demográficas e antropológicas estariam efetivamente implicadas na deriva matrimonial de um coletivo relativamente fechado e que peso relativo poderiam ter em cada caso?

- Em que medida tais variáveis operariam, sem que seus sujeitos, criadores e criaturas dessas redes delas tivessem consciência?

- Como uma rede matrimonial estaria articulada a outras redes de intercâmbio em uma dada população?

- Como distinguir aspectos demográficos e antropológicos triviais e não triviais nos anéis de uma dada rede?

- Como comparar os diferentes padrões "têxteis" de redes urdidas em populações de culturas distintas, a partir da análise dos "motivos" flagrados em sua tessitura (seus anéis)?

- Como poderiam ser interpretadas as diferenças de frequência, assim como a presença simultânea, de anéis de diferentes perfis em uma dada rede?

- Modelos mecânicos da antropologia do parentesco e modelos estatísticos da análise demográfica, voltados aos mesmos fenômenos sociais (casamento, família, isolados populacionais e assim por diante), poderiam ser harmonicamente integrados em um mesmo plano analítico?

0 enfrentamento de questões como essas, certamente, teria chances de produzir, no espírito de ambas as disciplinas, novas e inesperadas impressões. 


\section{Referências}

BOURDIEU, P. Les stratégies matrimoniales dans le système de reproduction. Annales: Économies, Sociétés, Civilisations, v. 27, n. 4, p. 1105-1127, 1972.

CAÑAS, V. Diários do Ir. Vicente Cañas, Manuscrito. Arquivo da Operação Amazônia Nativa, 1978-1987.

CEDI - Centro Ecumênico de Documentação e Informação. Povos Indígenas no Brasil: 1987/88/89/90, São Paulo, n. 18, 1990.

CORREIO DO POVO, Cuiabá, edições de 04/02, 05/02 e 11/02 de 1972.

DAL POZ, J.; SILVA, M. MaqPar - A homemade tool for the study of kinship networks. Vibrant, v. 6, n. 2, p. 29-51, 2009.

Informatizando o método genealógico: um guia de referência para a máquina de parentesco. Teoria e Cultura, v. 3, p. 63-7, 2010.

DUMONT, L. Introduction à deux theories d'anthropologie sociale: groupes de filiation et alliance de mariage. Paris: Mouton, 1971.

FERREIRA, C. E.; FRANCO, A. J. P.; SILVA, M. Finding matrimonial circuits in some Amerindian kinship networks: an experimental study In: IEEE 10TH INTERNATIONAL CONFERENCE ON E-SCIENCE. Anais... São Paulo: IEEE, 2014. v. 1, p. 73-80. Disponivel em: 〈http://ieeexplore.ieee. org/search/searchresult.jsp?searchWithin=\%22Authors\%22:.QT.Marcio\%20Ferreira\%20da\%20 Silva.QT.\&newsearch=true〉.

FLOWERS, N. M. Crise e recuperação demográfica: os Xavante de Pimentel Barbosa, Mato Grosso. In: SANTOS, R. V.; COIMBRA Jr., C. E. A. (Org.). Saúde e povos indígenas. Rio de Janeiro: Editora Fiocruz, 1994. p. 213-42.

FUNAI/DID/DGPI. Relatório. Brasília-DF: Fundação Nacional do Índio, incluído no Proc. FUNAI/ BSB/292/78. 27/11/1981.

GREGORY, C. Gifts and commodities. London: Academic Press, 1982.

HAMBERGER, K.; HOUSEMAN, M.; DAILLANT, I.; WHITE, D.; BARRY, L. Matrimonial ring structures. Mathématiques, Informatique et Sciences Humaires, 42 année, n. 4, p. 83-119, 2004.

HÉRITIER, F. L’ Exercice de la parenté. Paris: Gallimard/Le Seuil, 1981 (Coll. Hautes Études).

HOUSEMAN, M.; WHITE, D. Structures réticulaires de la pratique matrimoniale. L'Homme, v. 139, p. 59-85, 1996.

LÉVI-STRAUSS, C. Les structures élémentaires de la parenté. Paris: Mouton, [1949] 1967.

La famille. Le Regard Éloigné. Paris: Plon, [1956] 1983.

LISBOA, T. A. Os Enauenê-Nauê: primeiros contatos. São Paulo: Edições Paulinas, 1985.

LOUNSBURY, F. G. The structural analysis of kinship semantics. In: NINTH INTERNATIONAL CONGRESS OF LINGUISTICS. Proceedings... Mouton: The Hague, 1964. p. 1073-1093.

MISSÃO ANCHIETA. Documentos, incluído no Proc. FUNAI/BSB/292/78. 09/01/1978.

MURDOCK, G. Social structure. New York: Macmillan, 1949.

O ESTADO DE S. PAULO, São Paulo-SP, edição de 14/08/1974.

PAGLIARO, H. A revolução demográfica dos povos indígenas: a experiência dos Kaiabi do Parque Indígena do Xingu, Mato Grosso. In: PAGLIARO, H.; AZEVEDO, M. M.; SANTOS, R. V. (Org.). Demografia dos povos indígenas no Brasil. Rio de Janeiro: Editora Fiocruz; Associação Brasileira de Estudos Populacionais -Abep, 2005. p. 79-102. 
RICHARD, P. Étude des renchaînements d'alliance. Mathématiques et Sciences Humaines, v. 123, p. 3-35, 1993.

RIVERS, W. H. R. The genealogical method of anthropology inquiry. Sociological Review, v. 3, p. 1-12, 1910.

RONDON, C. M. S. Publicação no 2. 2. ed. Rio de Janeiro: Comissão Rondon, 1945. Anexo 5.

SÁ, C. A. As fases da vida: categorias de idade Enawene(ro) Nawe. Cuiabá: Operação Amazônia Nativa, 1996.

SANTOS, G. M. Da cultura à natureza: um estudo do cosmos e da ecologia dos Enawene-Nawe. Tese (Doutorado) - Faculdade de Filosofia, Letras e Ciências Humanas, Universidade de São Paulo - USP, São Paulo, 2006.

SILVA, M. Tempo e espaço entre os Enawene-Nawe. Revista de Antropologia, v. 41, p. 21-52, 1998. . Relações de gênero entre os Enawene-Nawe. Tellus, v. 1, p. 41-65, 2001.

. A aliança em questão: observações sobre um caso sul-americano. In: QUEIROZ, R. C.; NOBRE, R. F. Lévi-Strauss: leituras brasileiras. Belo Horizonte: Editora UFMG, 2008. p. 301-324 (Série Humanitas).

. Dinâmicas da vicinalidade entre os Enawene-Nawe. In: AMOROSO, M. R.; SANTOS, G. M. (Org.). Paisagens ameríndias. São Paulo: Terceiro Nome, 2013. p. 17-44.

. Liga dos Enawene-Nawe - um estudo da aliança de casamento na Amazônia Meridional. Tese (Livre Docência) - Faculdade de Filosofia, Letras e Ciências Humanas da Universidade de São Paulo - USP, São Paulo, 2012.

SILVA, M.; SÁ, C. A. Dados e indicadores demográficos dos povos indígenas atendidos pelo Polo Brasnorte, do Distrito Sanitário Especial Indígena - Cuiabá. In: OPAN. Controle social na saúde indígena: a experiência da Opan em Brasnorte, MT. Cuiabá: Editora da Opan, 2013. p. 55-78.

TRAUTMANN, T. R.; BARNES, R. H. "Dravidian”, “Iroquois”, and “Crow-Omaha” in North American perspective. In: GODELIER, M.; TRAUTMANN, T. R.; TJON SIE FAT, F. E. Transformation of kinship. Washington and London: Smithsonian Institution Press, 1998. p. 27-58

WEISS, M. C. Contato interétnico. Perfil de saúde-doença e modelos de intervenção em saúde indígena - o caso Enawene-Nawe em Mato Grosso. Tese (Doutorado) - Fiocruz, Escola Nacional de Saúde Pública, Rio de Janeiro, 1998.

WHITE, D. Ring cohesion theory in marriage and social networks. Informatique, Mathématique et Sciences Humaines, v. 168, n. 4, p. 59-82, 2004.

\section{Sobre 0 autor}

Marcio Silva é doutor em Antropologia pelo Museu Nacional da Universidade Federal do Rio de Janeiro e mestre em Linguística pelo Instituto de Estudos da Linguagem, da Universidade Estadual de Campinas - Unicamp. Professor titular do Departamento de Antropologia, da Faculdade de Filosofia, Letras e Ciências Humanas, da Universidade de São Paulo - USP. Fez pesquisa linguística entre os Kamayurá (Alto Xingu) e etnográfica entre os Waimiri-Atroari (Amazônia Setentrional) e Enawene-Nawe. Sua pesquisa atual tem como tema o tratamento computacional do parentesco. 


\title{
Endereço para correspondência
}

Rua Capote Valente, 1307 apto. 105

05409-003 - São Paulo-SP, Brasil

\begin{abstract}
Demography and anthropology in counterpoint: the Enawene-Nawe and their matrimonial drifts
\end{abstract}

This article has a twofold objective, one is of documental character and the other of theoretical nature. On the one hand, it aims to provide information that allows to outline the demographic profile of an Amerindian people in the Brazilian Southern Amazon, and contrast this quantitative data with anthropological information, in the key of the native ideas and values that are, in some ways, implicated in this profile. It is expected that such a combination may yield meanings that are lacking when these series of data are considered separately, as is the case in a musical counterpoint. On the other hand, the article draws attention to the analytical interest of an empirical phenomenon that is rarely explored, though frequently intuited in ethnographic research: the networks of "matrimonial rings" weaved by these peoples. The study of these networks brings to the forefront a region of interdisciplinary frontier that demands a deepening of the dialogue between the demography of small scale societies and the anthropology of kinship, both concerned, in their own ways, with the forms of reproduction of these collectives.

Keywords: Enawene-Nawe. Demography and anthropology. Relationship. Wedding rings.

\section{Resumen}

Demografía y antropología en contrapunto: los Enawene-Nawe y sus derivas matrimoniales

Este artículo tiene doble objetivo: uno de carácter documental y otro de naturaleza teórica. Por un lado, su objetivo es proporcionar información que permita delinear el perfil demográfico de un pueblo amerindio de la Amazonia Meridional Brasileña y superponer informaciones antropológicas, que incorporan en la clave de las ideas y valores nativos, los aspectos que de alguna manera están involucrados en este perfil. La expectativa es que tal solapamiento, como en los contrapuntos musicales, pueda producir significados que están ausentes en los dos conjuntos de datos considerados de forma aislada. Por otra parte, tiene también como objetivo llamar la atención sobre el interés analítico de un fenómeno empírico raramente explorado, aunque a menudo intuido por la investigación etnográfica: las redes de "anillos matrimoniales" tejidas por estos pueblos. El estudio de estas redes trae a primer plano una región fronteriza interdisciplinaria que exige un mayor diálogo entre la demografía de las sociedades de pequeña escala y la antropología del parentesco, ambos interesados, cada uno a su manera, en las formas de reproducción de estos colectivos.

Palabras claves: Enawene-Nawe. Demografía y antropología. Parentesco. Anillos matrimoniales.

Recebido para publicação em 28/11/2015 Recomendado para publicação em 10/06/2016

Aceito para publicação em 08/08/2016 